\title{
SH12 - La Educación de los Pueblos Originarios de Guatemala
}

\author{
René Humberto López Cotí \\ Doctorado en Educación \\ Universidad de San Carlos de Guatemala
}

\section{Resumen}

$\mathrm{C}$ onsideramos que una de las cuestiones que está limitando el acceso a la educación está directamente relacionada con la diversidad cultural presente en el país, concretamente estamos hablando de la diversidad que presentan los pueblos originarios, siendo ésta la población que más sufren el analfabetismo global, generándose una situación de discriminación con el resto de sectores populares. Guatemala es uno de los países que tiene mayores índices de analfabetismo en el mundo, situándose la tasa de estudios primarios en el $59 \%$ en jóvenes de 20 a 29 años, y todo ello después de veinte años de esfuerzos políticos por desarrollar una educación primaria universal y gratuita que permita a los ciudadanos mejorar su calidad de vida facilitando la igualdad de oportunidades en cuanto a la participación social, que es uno de los factores fundamentales para la cohesión social. Por eso es necesario realizar un análisis sobre el bajo índice de alfabetización registrado, sus consecuencias, y establecer el debate necesario para identificar las causas que están generando estás dificultades para alcanzar mayor cobertura de educación, ya que ésta nos capacita poder participar activamente en la consecución de los derechos colectivos, que son esenciales para la dignidad del ser humano, y para ello, un proceso democrático precisa de personas que participen activamente y en ello es fundamental contar con individuos debidamente alfabetizados.

Palabras clave: Interculturalidad, educacion, pueblos originarios, diversidad cultural.

\section{Abstract}

$\mathrm{W}$ e believe one of the issues that are limiting access to education is directly related to this cultural diversity in the country. We are specifically talking about the diversity found in indigenous peoples, which is the population who suffers most from global illiteracy, giving rise to a situation of discrimination, together with other popular sectors. It is well known that Guatemala is one of the countries in the World with highest illiteracy rate, reaching the 59\% in youngsters between 20 and 29 , and, in all cases, this was after 20 years of political efforts aiming at an universal free primary education to let the citizens improve quality of life and facilitating equal opportunities in social participation, being this one of the essential factors for social cohesion. There fore it is necessary to perform an analysis of the low rate of registered literacy and its consequences, and to establish the necessary debate to identify the causes generating these difficulties to achieve greater coverage of education, since it enables us to actively participate also in the achievement of collective rights, which are essential for human dignity. For this purpose, a democratic process requires people to actively participate. And it is essential in the process to have properly literate individuals.

Keywords: Quality of life;Intercultural education;original people;racism;cultural diversity. 